International Review of Social History 44 (1999), Supplement, pp. 15-3I

(C) 1999 Internationaal Instituut voor Sociale Geschiedenis

\title{
Family Concerns: Gender and Ethnicity in Pre-Colonial West Africa
}

\author{
SANDRA E. GREENE
}

For at least the past twenty years, historians of pre-colonial Africa have studied gender and ethnic relations, but have focused on either gender or ethnicity without making reference to the other. This essay redresses this neglect by demonstrating that changes in gender and ethnic relations within pre-colonial Africa so profoundly influenced each other that it is impossible to understand one without also taking into consideration the other. Documenting this intersection requires more than simply reconstructing how ethnic groups (in their efforts to compete with others for social and political status) altered gender relations within their societies by handling differentially the affairs of their female and male members. It involves more than analyzing how those disadvantaged because of their gender used the prevailing ethnic relations to ameliorate their own situations, and how these actions in turn altered ethnic relations in the societies in which they lived. It requires as well that we reconceptualize the very definition of ethnicity.

All too often, terms that define particular social categories provide an exclusive racial, ethnic, class or gendered definition. We ignore intersections among these categories. In far too many African historical studies, for example, African men have been defined as representatives of their ethnic groups and as such are described according to their ethnicity. Women are simply women, an undifferentiated and marginalized mass that by implication played no role at all in shaping the content of their own identities or that of others.' By analyzing as intimately connected the changes that were occurring in both gender and ethnic relations among the pre-colonial Anlo-Ewe (in what is now south-eastern Ghana), I explode this notion and prove instead that among the Anlo, both men and women were viewed and viewed themselves as integral members of their clan, a social unit that also provided them with their ethnic identity and social standing within Anlo society; and it was because of this degree of identification that males and females alike throughout the history of the Anlo were deeply involved in both supporting and undermining the boundaries that defined "we" and "they" in pre-colonial Anlo. One cannot speak of ethnic men and nonethnic women. Gender and ethnicity overlapped in ways that determined

I. John Lonsdale, "When Did the Gusii (or Any Other Group) Become a Tribe?", Kenya Historical Review, 5 (1997), pp. 123-133, and “African Pasts in Africa's Future", Canadian Journal of African Studies, 23 (1989), pp. 126-146; Leroy Vail, "Introduction: Ethnicity in Southern African History", in Leroy Vail (ed.), The Creation of Tribalism in Southern Africa (London, 1989), p. I5. 
the course of social change among the Anlo during the pre-colonial period. One cannot as well speak of men and women as if these categories were defined simultaneously by both gender and ethniciry alone. In pre-colonial Anlo, age differentiated younger women from older women, younger men from older men. Age gave individuals authority over the young, especially in their own families. Similarly personality differences played a role in how individuals chose to respond to specific situations. All these factors (gender, ethnicity, age, and personality) operated in ways that defined a society that was stratified less by economic differences and more by social standing within the community. Some (those who were elderly, respected, and of a particular ethnicity) found their voices much more influential than others because of the combination of social and individual characteristics that came together in their persons. Others found themselves disadvantaged because of their gender, ethnicity, age, and/or personality. Still others fought against their disadvantaged position by challenging the norms that governed social hierarchical relations in Anlo society.

Documenting these events as they unfolded in late seventeenth-, eighteenth- and nineteenth-century Anlo involves a creative use of sources that rarely speak directly to the issues of gender, ethnicity and social stratification. As an oral society, the Anlo have maintained extensive traditions about the history of various clans and how these clans were defined ethnically, but rarely do these traditions speak of the changes that were occurring in the ways the Anlo ethnically defined "we" and "they". Similarly, the oral traditions say virtually nothing about the role women played in defining ethnic categories or changing the number and content of those categories. What we do know, from more recent missionary and ethnographic accounts, however, is that marital arrangements were key to maintaining and challenging ethnic boundaries and that young women were central to these challenges since it was their bodies over which so many sought control. By combining these bits and pieces of information - oral accounts about "we" and "they", written accounts about the role of marriage in structuring and destroying social boundaries, the predominant emphasis on female recruitment to religious orders developed and maintained by ethnic outsiders, and the incredible competition that developed during the era of the slave trade for control over women - it is possible to reconstruct through both circumstantial and direct evidence how gender and ethnicity (along with age) were profoundly and intimately connected in pre-colonial Anlo.

To consider gender and ethnicity as historically inseparable where both men and women, young and old, were primary actors in generating change allows us to avoid the all too frequent tendency to martyr the disadvantaged as they resist their marginalization and to demonize those in power. This tendency exists in a number of studies in pre-colonial African women's 
history. ${ }^{2}$ In my own work, I document, as do so many other scholars, how male-dominated patrilineages and clans exercised far more control over the productive and reproductive capacities of the young women than the young men in eighteenth- and nineteenth-century Anlo. But I avoid demonizing African men or those African elders (older men and older women) who controlled the fate of the young women under their authority. I do so by discussing the increasing pressures felt by family elders as a result of demographic changes and the competition for prestige that arose because of the expanding influence of the Atlantic slave trade. Rather than excuse or deny the negative impact that decisions made by largely male elders (but also by female elders) had on young women, I emphasize the particular historical context in which these elders acted in order to meet specific challenges, not simply to make the lives of the young women in their families miserable. Social history thus becomes a field that examines the relationship between the powerful and the average, where both are given a voice, where the role of the historian is to unravel the complex reasons why individuals and groups acted as they did. This definition avoids creating stark oppositions between good and bad individuals, oppressor and oppressed that is largely incongruent with the complex realities of human relations.

By focusing on both gender and ethnic relations as intimately connected phenomena (where age and personality also played a role), I also bypass the failure of some women's studies scholars to acknowledge the fact that gender relations in Africa historically have been deeply and intimately affected by such issues as race even when race as a category meant little in the social hierarchies of the pre-colonial societies studied. As a field, African history including African gender and women's history - has laboured under the racial stigmas that have been imposed on Africa and Africans since at least the eighteenth century. These stigmas vilify both African women and African men, associating them with some of the most venal stereotypes reserved for those defined as the ultimate "other" of Western culture and civilization. In the last twenty-five years, however, the growth in women's studies as a field has generated a massive body of scholarship that counters these myths especially as they pertain to African women. This literature documents the extent to which African women often held powerful economic, religious and political positions within their societies, how they resisted exploitation by both African and European men, how they organized their own institutions to reinforce existing social hierarchies or to develop more egalitarian self-help institutions, how class, age and racial

2. I. Wilks, Wa and the Wala (Cambridge, 1989); Robert Launay, Traders without Trade (Cambridge, 1982); Kwame Arhin, "Strangers and Hosts: A Study in the Political Organization and History of the Atebubu Town", Transactions of the Historical Saciety of Ghana, 12 (1971), pp. 63-81; Toyin Falola, "From Hospitality to Hostility: Ibadan and Strangers, 1830-1904", Journal of African History, 26 (1985), pp. 51-68. 
differences among women have been used by some women to enhance their own positions and/or disadvantage others. ${ }^{3}$ In contrast, the literature on African men as gendered individuals is quite limited ${ }^{4}$ - an imbalance that bolsters a particularly negative image of African men since there is little to counter the stereotypes that have been generated for centuries. More significantly, much of the literature on African women reinforces this negative imagery by highlighting the disadvantaged situation of African women vis-à-vis men by vilifying the latter. By considering gender and ethnic relations as historically inseparable phenomena, I can better challenge both explicitly and implicitly racist formulations that describe African men as demons devoted to the subordination of African women for no apparent reason.

To illustrate the significance of the intersections of gender and ethnicity and their importance for understanding the history of pre-colonial African social stratification, I begin by documenting political changes in the late seventeenth century in what was then known as the lower Gold Coast. These changes sparked demographic shifts, a reconfiguration in ethnic boundaries and transformed the way Anlo families managed the affairs of the young men and women under their authority. Anlo youth were increasingly encouraged to marry individuals chosen by their male and female family elders, whether they agreed with the choice of their marital partner or not. However, young women bore the brunt of this system. Additional disadvantages accrued during the late eighteenth and nineteenth century as families came under increasing pressure to restrict even further the marital options for their young. Reactions of some young men and many young women to these familial actions generated major changes in Anlo sociery that not only altered their own lives as gendered individuals, but also profoundly changed the nature of both gender and ethnic relations in Anlo society during the pre-colonial

3. For a brief discussion of the history of African women's history in relation to other area histories within women's studies, see Sandra E. Greene, "A Perspective from African Women's History: Comment on 'Confronting Continuity', Journal of Women's History, 9 (1997), pp. 95-104.

4. This, of course, has much to do with the fact that scholarly interest in masculinity is relatively recent in comparison with the more developed field of women's studies. Some recent studies on African masculinity include Janet Bujra, "Men at Work in the Tanzanian Home: How Did They Ever Learn?", in Karen Tranberg Hansen (ed.), African Encounters with Domesticity (New Brunswick, NJ, 1992), pp. 242-265; Gerald Keis and Salisu A. Abdullahi, "Masculine Power and Gender Ambiguity in Urban Hausa Society”, African Urban Studies, 16 (1983), pp. 39-53; Shire Chinjerai, "Men Don't Go to the Moon: Language, Space and Masculinity in Zimbabwe", in Andrea Cornwall and Nancy Lindisfarne (eds), Dislocating Masculinity (New York, 1994), pp. 147-158; Lisa Lindsey, "No Need [...] To Think of Home?': Masculinity and Domestic Life on the Nigerian Railway c.1940-6I", Journal of African History, 39 (1998), pp. 439-466; and the special issue on masculinities in Southern Africa in the Journal of Southern African Studies, 24 (1998). There is, in addition, a growing literature on homosexuality among African men, a topic that at times also touches on issues of masculinity. 
period. We see this in the late eighteenth century when young Anlo women - either on their own or with encouragement from their mothers - joined the Dzevi's Nyigbla religious order. Many did so to gain more leverage as wives in their marital households, but the results of their actions also successfully challenged the social boundaries that had stigmatized the Dzevi as outsiders. We see it again in the midnineteenth century when young women flocked to ethnic outsider Elias Quist's Yewe religious order in defiance of their parents' wishes. Again many of these young women joined this order to marry whom they wished, but in being so successful in recruiting and retaining so many young women, Quist successful entered the social elite of Anlo society and altered the boundaries that defined "we" and "they". Both examples illustrate the extent to which gender and ethnic relations, and changes therein, were intimately and profoundly connected with one another.

GENDERED RESPONSES TO ETHNIC CHALLENGES: ANLO IN THE LATE SEVENTEENTH AND EIGHTEENTH CENTURIES

In 1679, an undetermined number of refugees flooded eastward out of the lower Gold Coast in an effort to escape the advancing armies of the Akwamu state to dominate the trade in slaves, gold and European commodities at Accra. Many sought and received permission to settle in Anlo, an area situated like their own former homelands, on the Atlantic littoral but located just east of the Volta River. In I702, however, Akwamu conquered Anlo as well. Akwamu citizens entered the area as administrators; they forcefully established themselves in the Anlo capital, Anloga, and then assumed the right to maintain order and to muster troops for additional military campaigns.

For those who had been resident in Anlo well before any of these developments, the presence of large numbers of refugees, and new residents who exercised considerable political power over the area, required a response. Earlier resident families grouped themselves together into new social units known as blowo (clans) as a means of socially distinguishing themselves from others. They acted to protect their rights to the limited arable resources in the area, a course taken because of the geographical characteristics of the Anlo area. The total land area of Anlo in the late seventeenth century was approximately ninety-four square miles. Three-quarters of this consisted of swamps, creeks and low-lying salt-laden, clayey soils that could support little cultivation. The areas suitable for farming, less than twenty square miles, were placed under a system of shifting cultivation that yielded one crop per year. This method necessitated that each household have land in sufficient quantity to allow portions to be fallow, while the remainder provided the 
food requirements of the household.' Even these lands were subject to periodic flooding - a situation that often forced the Anlo to obtain food from the northern side of the lagoon. One such flood occurred in 1683 , four years after the first wave of refugees moved into the area from the $\mathrm{Ga}$ and Adangbe districts of Accra and Ladoku. ${ }^{6}$ Because of the scarcity of arable land resources, the increase in population resulting from the three or four successive waves of refugees between 1679 and 1702 and the floods in 1683 , the earlier residents of Anlo organized themselves into clans in order to guarantee for themselves and their future generations access to the land needed for their subsistence. Control and distribution of clan land for the benefit of clan members was at the heart of the development of the clan system.

In creating the clan system, the earlier residents of Anlo not only developed a new social unit within their society, they also altered the way in which the community defined we/they relations. Anlo oral traditions indicate that when the first Ewe-speaking immigrants entered Anlo from the town of Notsie (presently located in south-central Togo), they encountered others already occupying the area. Numbering seven in all, this autochthonous population is said to have lived alongside the Ewe immigrants for some time. Later, however, they disappeared. In recognition of the notion that the autochthons as the first inhabitants of the area had spiritual authority over the land on which the immigrants were now resident, several of the Ewe lineages deified the autochthons and took responsibility for their worship. ${ }^{7}$ These accounts - as is often true with other oral traditions - may or may not depict in precise historical detail the events described therein. They are important, however, because they do indicate that the Anlo population at one time, identified itself as a community composed of two groups: one associated with a set of gods that had power over the land, and another set that had custody of those gods brought to Anlo by immigrants from the town of Notsie. The entrance after I 679 of additional immigrants challenged the prevailing conception of we/they relations. Faced with the threat of having to compete for the limited arable land resources in an area that they had occupied for some time, the earlier resident groups retained their identities as lineages affiliated with either autochthonous or immigrant gods, but they elevated to much greater importance invented traditions that they were nevertheless all descendants of the same set of related ancestors and shared

5. For a more detailed discussion of this see, Sandra E. Greene, "Land, Lineage and Clan in Early Anlo", Africa: The Journal of the International African Institute, 5 (1981).

6. Sec Sharon Elaine Nicholson, "A Climatic Chronology for Africa: Synthesis of Geological, Historical and Meteorological Information and Data", (Ph.D. dissertation, University of Wisconsin, Madison, WI, 1976), p. I25.

7. See Sandra E. Greene, Gender, Ethnicity and Social Change: A History of the Anlo-Ewe (Portsmouth, NH, 1996), introduction and ch. 2. 
an association with Notsie, their common ancestral home. ${ }^{8}$ As a group, they stood as one, ethnically distinct from all others. Those who entered the area after 1679 were denied access to land and socially stigmatized as "other". They came late; they had different geographical and genealogical origins; they were ethnic outsiders.

Clan formation also generated changes in the way in which earlier resident Anlo families managed the lives of their young. Studies of the lineage inheritance system that obtained among the Anlo and other Ewe-speaking peoples in the area indicate that at one time all practiced patrilineal inheritance, where daughters as well as sons received from their mothers and fathers land which they could pass to their own children even if the latter, by descent, were members of a different patrilineage. This is said to have been the case in the I860s and I870s; it was also true in the early I900s. Land could be inherited from both father and mother. ${ }^{9}$ In most cases, the brothers of a woman who received land from her patrilineage would attempt to retrieve the land after her death or after the death of her children so that the property was not lost to their patrilineage. Among the Anlo, however, the land given to a daughter would be left with her and her children to be absorbed into the latter's patrilineage. No mechanism existed within the Anlo lineage system of inheritance to limit the transfer of property to a different patrilineage, save through the diminution in the amount of land allocated to the daughter. ${ }^{\text {10 }}$

If this same system existed in the seventeenth century, the influx of refugees that entered and remained in Anlo after 1679 would have severely tested the provision that allowed land to pass out of the control of a particular lineage. Arable land was limited and it is almost certain that marriages occurred between local women and some of the immigrants. Traditions that discuss the particularly close relations that existed between specific stranger groups and earlier residents indicate that it was not uncommon for relations between these two to be reinforced through marriage. ${ }^{\text {II }}$

8. Ibid., introduction.

9. Cited in J. Dickson, "Marital Selection Among the Anlo Ewe of Ghana: From Parental to Individual Choice", (Ph.D. dissertation, Duke University, Durham, NC, 1982), pp. 79-80.

Io. A.K.P. Kludze, "Family Property and Inheritance Among the Northern Ewe", p. 208; D.K. Fiawoo, "Ewe Lineage and Kinship: Sub-Ethnic Group Variation", p. 165; T. Kumekpor, "The Position of Maternal Relatives in the Kinship System of the Ewe", p. 213; all in Christine Oppong (ed.), Legon Family Research Papers: Domestic Rights and Duties in Southern Ghana, (Legon, 1974); G.K. Nukunya, "Land Tenure, Inheritance and Social Structure Among the Anlo", Universitas, 3 (1973), p. 72, and Kinship and Marriage Among the Anlo-Ewe (London, 1969), pp. 43-44, 46. Michel Verdon, The Abutia Ewe of West Africa: A Chiefdom that Never Was (Berlin, 1983), p. 125, and Dickson, "Marital Selection", pp. 81-82; note the existence of the separate system of homogeneous transmission as applied to personally acquired, less valuable property.

II. Sandra E. Greene, Field Note 16: Interview with Togbui Le II, I6 August 1978, Anloga, (on deposit with the author), Special Collection (SC) 14/2, Pp. 125-127, 187; SC 14/3, p. 272, (Ghana National Archives, Accra, Ghana). 
Residential proximity to one another within the wards, and a preference for in-ward marriages that seems to have existed among all Ewe groups, facilitated such a development. The generation produced by these marriages (a generation that the Anlo defined technically as strangers) would have been in a position to compete quite effectively for the limited resources in the area. The descendants of an immigrant male and a local woman would have had three avenues of access to land. They could inherit property from their fathers, who in turn might have gained access to the same because it was unclaimed land or because it had been given to them as a gift. They could inherit from their mothers. Like their fathers, they could claim land that had not been possessed by others. These were the same avenues open to the children born of two local parents.

Given the competitive pressures probably created by geographical constraints and an inheritance system not structured to maintain access to land within a particular patrilineage, the Anlo developed not only a clan system to protect their interests. They also created a preference for clan endogamy to deal with the competition over limited resources and the inadequacy of the lineage system in coping with the problem. ${ }^{\mathrm{I}}$

Unfortunately for the young women in these earlier resident lineages, the development of the clan system and the preference for clan endogamy came at their expense. For while both young males and females were increasingly forced to marry members of their clan whatever their wishes, the polygynous character of Anlo society allowed males, no matter their actual financial means, to at least aspire to contracting additional marriages with women of their own choosing. Women had no such options. This preference for marriage within the clan joined the already pre-existing preference for marriages between families that lived in the same residential areas. Thus with the development of the clan system and the preference for clan endogamy, ethnic insider women found their ability to influence their own marriages increasingly restricted. The development of the clan system rendered a woman's clan affiliation irrelevant for her children (since - unlike the lineage system - the children took their affiliation only from their father) yet in the context of marriage, her clan affiliation became more important than that of her brothers. If a woman's brother was betrothed to a woman of a different clan, the land he inherited from his father would remain in the clan because those who could inherit from him included his own children and the children of his sisters. If, however, a woman married a man of a different clan, her land would be lost to her clan because her children belonged irrevocably to the clan of their father. Thus, the earlier resident families in Anlo chose to defend their rights to the arable resources in the area by strongly encouraging - and in some instances forcing - the women

I2. D. Westermann, "Die Glidyi-Ewe", Mitteilungen des Seminars für Orientalische Sprachen, 38 (1935), p. I44; Nukunya, Kinship and Marriage, p. 74. 
in their families to marry someone who both lived in the same ward as the woman's family and was also a fellow clan member.

During the eighteenth and into the nineteenth century ethnic outsiders, for very different reasons, also increased control over the women in their families. This is most evident with the Amlade, a group that entered the Anlo area from Anexo as part of this state's invasion and conquest of the Anlo in 1742. In 1750 Anlo managed to free itself, but many from Anexo who stayed coalesced into their own clan known as the Amlade and established a reputation for themselves in Anlo as a group associated with particularly powerful gods. They installed in their new homeland their god, Togbui Egbe, which had the ability to incapacitate seriously those with whom the Amlade argued. Another god, Sui, proved powerful enough to demand payment for its services in the form of a fiasidi, a young woman who remained as a servant associated with the Sui shrine for the rest of her life and who on her death had to be replaced by her family with another female family member. Of greater importance here is that the Amlade despite their ethnic outsider origins - were able to obtain membership in the highest political and religious circles in Anlo by reinventing the traditions that recounted their origins. They did so with the help of a number of allies within the Anlo political elite, but also by exercising much greater control over the women in their families. ${ }^{13}$ Nineteenth-century descriptions by German missionaries noted that the Anlo expected a wife to know a great deal about her husband's clan. It was her responsibility to introduce their children into the culture of the father's clan. ${ }^{14}$ Failure to do so could lead to potentially harmful consequences for those children. This education imperative appears to have affected how the Amlade families managed the marital affairs of their daughters.

Strongly urging daughters to marry within the clan in order to retain land holdings could not have been the factor that motivated the Amlade to adopt this practice, however. They did not possess any land as a corporate unit, even though they did indeed favor marriages within the clan as did other ethnic outsider clans in Anlo. ${ }^{\text {IS }}$ Several possibilities exist to account for this preference. Perhaps the various patrilineages that together formed the Amlade clan were few in number and therefore to strengthen their numerical position within Anlo they chose to betroth their daughters to men within the clan. A second possibility may have involved the imperative the Amlade must have felt to maintain control over the socialization of their children because of the change in identity they were attempting to affect

13. For a more complete discussion of Amlade origins and their history in Anlo, see Greene, Gender, Ethnicity and Social Change, Pp. 6I-67.

I4. Westermann, "Die Glidyi-Ewe", p. I43; J. Spieth, "Von Den Evhefrauen", Quartalblatt der Norddeutschen Missionsgesellschaft, 6 (I889), p. 6.

15. Westermann, "Die Glidyi-Ewe”, pp. I42-145; Greene, Field Note 16: Interview with Togbui Le II, 16 August 1978, Anloga; Nukunya, Kinship and Marriage, p. 23. 
during the late eighteenth century. As ethnic outsiders, they were technically barred from holding any high position within the Anlo polity. Yet by the early nineteenth century, they had the right to enstool the paramount chief, the awoamefia, and to pray on behalf of the entire polity. They accomplished this by working with political allies to alter their history to emphasize a connection by descent to the original homeland of those who traditionally held authority in Anlo. They also used their connections with powerful gods to threaten those who offended them. They then supplemented these efforts by giving their daughters in marriage to men within their own clan. By doing so, Amlade parents could more safely assure that their own daughters would teach their children to view themselves as members of a clan that was indeed genealogically and spatially connected to the earliest Anlo families in the original homeland, Notsie. This latter effort required that Amlade young women sacrifice their own marriage plans for the sake of the clan. That many Amlade women willingly and/or unwillingly married fellow clan members is supported by the fact that they practiced clan endogamy at the same rate as others in Anlo. Thus, when the Amlade redefined themselves as ethnic insiders, they also reordered gender relations within the clan in order to reinforce their new ethnic identity. This reordering, however, had the same impact on gender relations as the reordering that occurred among the earlier immigrants to Anlo: families opted to alter the ways in which they handled the affairs of the young men and women over whom they had authority by placing far more restrictions on their young women than their young men. Thus, by the end of the nineteenth century, young women of Anlo - whether members of ethnic insider or ethnic outsider families - found their voices increasingly silenced in comparison with their brothers when it came to decisions that affected their own bodies. This situation developed in large part from the changing character of ethnic relations with Anlo society.

The construction and reproduction of these new ethnic and gender relations was not solely the concern of male household heads. Older women actively participated in the decision-making bodies of their clans and lineages and participated actively in both designing and implementing the way in which gender relations would be altered to support the ethnic interests of the family. Many mothers, for example, supported the decisions made by male and even older female family elders by encouraging their children, especially daughters, to acquiesce in the limitations imposed on them by the various preferences that came to govern Anlo marital relations. Included as part of this education was an emphasis on the desirability of marrying someone within one's own clan. Children whose mothers and fathers belonged to the same clan expressed great pride in that fact. ${ }^{16}$

16. Gottlob Binetsch, "Beantwortung mehrerer Fragen über unser Ewe-volk und seine Anschauungen", Zeitschrift für Ethnologie, 38 (1906), p. 13; Spieth, "Von der Evhefrauen", p. 6; Westermann, "Die Glidyi-Ewe", p. 143. 
Older women's interests in supporting the Anlo preferences for clan endogamy and even young women's willingness to go along with this socialization suggests that most women took seriously the ideology that family members, male and female, should support their kin-group over their individual interests when family interests were threatened and when the family had the opportunity to benefit from particular conditions or changes. This ideology is evident in the strong prescriptions that outlined the responsibilities each clan member had to support and defend the $h l o .{ }^{17}$ So many families were successful in encouraging their daughters to accept many restrictions on the powers they had over their own bodies. Thus, older women and younger ones protected the interests of their kin- and ethnic group, even if this meant sacrificing their own interests or the interests of their daughters.

\section{ETHNIC AND GENDERED RESPONSES TO THE CHALLENGE OF MARGINALIZATION: ANLO IN THE LATE EIGHTEENTH CENTURY}

By the end of the eighteenth century, Anlo women - whether members of ethnic insider or ethnic outsider families - found their voices increasingly silenced by the elders within their lineages and clans. Rivalry during the eighteenth century between earlier residents and those who entered Anlo after 1679 had prompted both to form themselves into separate sets of clans and to urge their young women strongly to marry fellow clan members. Late eighteenth- and nineteenth-century European accounts have indicated that by this period some young women had begun to challenge successfully certain aspects of this system. The history of the Dzevi clan and the Quist family, both defined by the Anlo as ethnic outsiders, best reveal these challenges. The Dzevi entered Anlo as $\mathrm{Ga}$ - and Adangbe-speaking refugees after I679. The Quist family defined themselves and were defined as ethnic outsiders because they were the patrilineal descendants of a Danish officer who had been stationed on the west African coast during the late eighteenth century. Both significantly were also associated with influential religious orders during a pre-colonial period when political influence was inextricably linked with religious authority in Anlo. The more powerful one's reputation for exerting spiritual influence over worldly events, the more influential one became.

In 1769 an unprecedented event occurred in Anlo when an ethnic outsider clan, the Dzevi, rose to power. This clan demanded with the support of the Anlo population that the awoamefia - the most powerful leader in Anlo - share authority with them. The Dzevi could make such demands because their god, Togbui Nyigbla, had brought them victory in battle at a

17. For a more detailed discussion of these prescriptions, see Greene, Gender, Ethnicity and Social Change, p. 31 . 
particularly critical time for the political and economic welfare of the entire Anlo polity. ${ }^{18}$ Significantly, the Dzevi priest of the god Nyigbla, and his supporters, were able to maintain his position within the most powerful political and religious circles in Anlo throughout the remainder of the eighteenth and into the nineteenth century by successfully claiming that their god was responsible for additional military victories. Of greater importance here is the fact that the Dzevi obtained massive support from the women of Anlo for reasons that had little to do with its spiritual role on the battlefield.

Family pressure on women over marriage choice had increased throughout the eighteenth century, particularly after 1750 when the Anlo became more involved in the Atlantic slave trade. In order to compete better for prestige gained from conducting successful trade relations with Europeans, many Anlo families began to encourage their daughters not only to marry men from the same residential ward and fellow clan members, but also the sons of their mother's brothers. Such marriages would ensure that the labour of the children born to such marriages stayed within the family and such labour could generate the commodities that would facilitate more extensive involvement in the Atlantic slave trade. Thus, by the end of the eighteenth century, young women in Anlo were also encouraged - and at times, forced - to marry maternal cousins. Under such conditions, divorce also became more problematic, since these marriages brought families the potential to enhance their social and economic standing within the community. Divorce would undermine such efforts and thus became more difficult as the social stakes associated with maintaining marriage were raised.

This situation changed for many women when the Nyigbla order began to gain prestige within the Anlo polity. As part of the efforts to institutionalize its position among the political and religious elite, the Nyigbla order of the Dzevi clan began to recruit (with the support of most Anlo families) at least two women from every Anlo clan every year. According to nineteenth-century accounts, the Nyigbla order attempted to maintain the impression that the god itself called the recruited women. However, members of the order would encourage others to join and then the priest would instruct the recruits how to behave. This involved the young woman learning to behave as if she were slightly off-balance mentally. As one elder noted, "they were not normal any more, but not so abnormal that people thought they were totally crazy [...]. They would roam about [...] so parents were not totally surprised by the possibility [that they had been caught by the god]. ${ }^{n}$ Every year women responded to this recruitment effort and every year these new members, known as zizidzelawo, recruited others. Young

18. Ibid., pp. 82-86.

19. See H. Seidel, "Der Yewe Dienst in Togolande", Zeitschrift für Afrikanische und Oceanische Sprachen, 3 (1897), pp. I66-167, and Greene, Field Note 65: Interview with Togbui Dzobi Adzinku, 6 January 1988, Anloga. 
women undoubtedly had many reasons for joining this order. They gained prestige from affiliation with one of the most powerful gods in Anlo; membership may have provided an expanded set of contacts with potential social and economic benefits; others may have joined simply at the urging of their mothers. Of particular significance for our discussion here are the benefits that came to wives. Married women affiliated with this order gained considerable freedom of action within their husband's households. Accounts about such religious orders among the Ewe explain that:

[...] the kosio (the prepubescent initiates) and the vodu-viwo (the children who had been dedicated to the god) either did not marry or their marriages contained the potential for great instability because, as European traveler A. B. Ellis noted, "[...] the husband [...] [could] not punish her or reprove her for any excesses, sexual or other[wise $[\ldots]^{m}{ }^{20}$

Similarly, studies on Akan priestesses in the Fanti area indicate that "the husband of a priestess [had] to be extremely cautious not to 'abuse' her, lest he offend her deity and then have to appease it be a series of costly gifts" ${ }^{21}$

Women closely associated with gods, including the Nyigbla deity, thus gained considerable leverage within their marriages. By joining Nyigbla or encouraging their daughters to do so, many Anlo women took advantage of the opportunity to better protect their own interests in a climate where their natal and marital families were less prepared to do so. In pursuing this course, then, some young Anlo women, with the support of their mothers, not only took advantage of Nyigbla's popularity by consciously joining an order to gain greater freedom within their marital households. They also wirtingly or unwittingly - began to challenge those changes in gender relations that had begun to deny them the ability to participate in discussions about the fate of their own bodies. The support these women give to Nyigbla also challenged the prevailing character of ethnic relations in Anlo because this support helped institutionalize the Nyigbla priest's position within the Anlo political and religious hierarchy. With the inclusion of the Dzevi as ethnic outsiders in the ranks of the most influential political and religious groups came the first expansion in the definition of people deemed eligible to hold high political and religious office within the Anlo polity. The Dzevi's elevation to the position of sharing power with the Anlo awoamefia redefined the boundaries that separated ethnic insider from outsiders and which limited the latter's ability to wield influence within Anlo. Ethnic origins were still important, but service to the Anlo polity became an equally important marker of status. This change, in turn, opened

20. A.B. Ellis, The Ewe-Speaking Peoples of the Slave Coast of West Africa (Chicago, IL, I89o), Pp. I4I, I42; see also Greene, Field Note 33: Interview with Boko Seke Axovi, 3 October 1978, Anloga. 21. Robin Law, The Slave Coast of West Africa, 1550-I750 (New York, 1991) p. 114; and James Boyd Christensen, "The Adaptive Function of Fanti Priesthood", in W.R. Bascom and M.J. Herskovits (eds), Continuity and Change in African Cultures (Chicago, IL, 1959), p. 268. 
the door during the nineteenth century for other ethnic outsiders, like the Quist family, to become centrally positioned within the Anlo social hierarchy.

\section{GENDERED AND ETHNIC RESPONSES TO THE CHALLENGE OF MARGINALIZATION: ANLO IN THE NINETEENTH CENTURY}

Nyigbla's stature in Anlo declined precipitously in the early I80os. But it still played a prominent role within the political and religious cultures of Anlo between the early 1840s, when it again led the Anlo in battle, and 1874, when Anlo's defeat by the Europeans marked the beginning of its final decline as a war god. During this period, the Yewe religious order actively competed with Nyigbla by offering wives as well as young unmarried girls better support than available in the Nyigbla order. Affiliation with the Yewe religious order also proved central to the social elevation of the Quist family.

Because Nyigbla provided no recourse for young women who would have liked to refuse their elders' choice of a husband, the Yewe order took advantage of this and offered women the opportunity to select their own spouse and the time when they would marry. ${ }^{22}$ Yewe also offered married women a means to check the behaviour of abusive husbands when their own families were unwilling or unable to assist them. In both situations, advantages stemmed from the belief that an offence given to a Yewe member was an offence to her god. Evidence that the god had indeed been offended took the form of the Yewe woman behaving in an obviously possessed state. Thus, if a husband quarreled with his Yewe wife, beat her or insulted her, she could declare herself alaga, that is, someone who has gone wild, a right of all members of this religious order. Young unmarried female members also had this option. Former Yewe member, Stefano Kwadzo Afelevo, later explained that they were instructed to "go wild if [their] mother or father said something offensive to [them $]^{n}{ }^{23}$ Only by paying a fine to the Yewe priest or bubono could parents or the husband of a female alaga rectify the offence. According to a number of accounts from the late nineteenth century, these fines were often so large that the offender was forced to borrow the sum or place a relative in pawn. ${ }^{24}$ No doubt this action did much to

22. Stephen H. Kwadzo Afelevo, "Ein Bericht über den Yehwekultus der Ewe. Herausgegeben mit deutscher Übersetzung und Anmerkungen von D. Westermann", Mitteilungen des Seminars für Orientalische Sprachen, 33 (1930), p. 27.

23. Cited in Seidel, "Der Yewe Dienst", p. I7o.

24. To pawn an individual means that a person hand a relative, usually a child, to another in exchange for a loan. The child would live with the lender, working for him or her. The work the child performed for the lender would serve as interest on the loan. The child could not return to his or her family until the loan principle was repaid. For a more extensive discussion of pawning, 
strengthen a woman's voice in her natal and her husband's household, but it had other consequences as well. By the end of the nineteenth century, the ethnic outsider Elias Quist had become a major economic power and respected figure in Anlo in large part because of his association with Yewe and because of the support his Yewe order received from women who sought to challenge the way in which their families handled their marital affairs.

The history of Quist's association with Yewe began shortly after I847 when he was traveling westward from the coastal town of Anexo to Accra by boat. The vessel on which he was a passenger sank. A diviner attributed his near drowning to one of the Yewe gods, who was calling him to its service. Oral traditions indicate that these events set the stage for his involvement with the Yewe order. Heeding this call, he established a Yewe shrine and became its hubono, owner. ${ }^{25}$ Such a position required him to support financially the activities of the members of the order, to adjudicate disputes between members and non-members, and to manage many of the ritual affairs of its members. ${ }^{26} \mathrm{He}$ undoubtedly also - as required of bubonowo continued to provide assistance to and gain adherents from others the god had helped, but Quist did more than simply assume the expected role of a Yewe owner. He reorganized the way in which the order interacted with the community so that he could use the order to respond both to the changing business climate in the area ${ }^{27}$ and to meet the needs of those women disaffected with their families because of the increased restrictions these families had placed on the women's ability to control their own bodies.

By using the Yewe order in this way, Quist, as an ethnic outsider, gained tremendous support from and gave great assistance to Anlo women (no matter their ethnic identity). This, in turn, had profound consequences for the norms that governed Anlo gender and ethnic relations. Acceptance of Quist as a leading figure in nineteenth-century Anlo society significantly altered the boundaries that had previously defined "we" and "they" in precolonial Anlo. The notion that wealth alone (along with a shorter period of residency) could define a person or group as an integral and central member of Anlo society joined earlier emphases on connections to the ancestral homeland, time of arrival and contributions to the welfare of the polity.

That many women joined Yewe to defy the norms governing gender relations contributed to the tendency for other young men and women to

see Toyin Falola and Paul E. Lovejoy, Pawnship in Africa: Debt Bondage in Historical Perspective (Boulder, CO, 1994).

25. See Greene, Field Note 70: Interview with Mr Kwami Kpodo, 12 January 1988; and Field Note 92: Interview with Togbui Amegashi Afeku IV, i8 February 1988, Tema. See aiso SC $14 / \mathrm{r}$, p. 208; and Anlo Traditional Council Minute Book No. 3: 14/4/6-32/7/87, pp. 14-37 (Anloga Traditional Council Office, Anloga, Ghana).

26. Richard Tetteh Torgby, "The Origin and Organisation of the Yewe Cult", B.A. long essay, Department for the Study of Religion, University of Ghana, Legon (1977), pp. 24, 31.

27. For more discussion of this, see Greene, Gender, Ethnicity and Social Change, pp. 97-98. 
establish their own unions (concubinage) without the benefit of direct parental involvement, a formal marriage ceremony or association with the Yewe order. This, in turn, had a major impact on the gendered manner in which families managed the marriages of their youth. Parental authority declined. Young men, but especially young women, reasserted their right to pick their mates. ${ }^{28}$ In making such choices, young women not only successfully challenged the norms that governed gender relations in nineteenth-century Anlo, they also challenged the prevailing norms the defined ethnic outsiders like the Quist family as different, potentially dangerous and to be avoided and/or marginalized in all matters that affected the interest of ethnic insider families and the polity. This was the case because of the intimate connections that existed between ethnic and gender relations in Anlo.

\section{CONCLUSION}

This discussion of gender and ethnic relations among the Anlo-Ewe illustrates the importance of analyzing, as interconnected phenomena, shifts in the ways gender relations operated within the family and changes in the boundaries that the Anlo constructed to separate the ethnic "we" from the ethnic "they". When refugees flooded into the Anlo area and remained to compete with the earlier residents for access to the limited arable land in the district, the earlier residents not only redefined the boundaries that defined ethnic insiders and outsiders to limit the abilities of the newcomers to influence the affairs of the polity, they also altered the gendered manner in which they handled the marital affairs of their young. In response to these exclusionary practices, those marginalized because of their outsider status adopted for different reasons the same gendered marital practices introduced by the ethnic insiders. Those most affected by these changes the young women in both ethnic insider and outsider families - then reacted to demands that they and not their brothers sacrifice their interests for the sake of their families by joining religious orders organized by a number of ethnic outsiders. In coming together in the context of these new religious groups, those stigmatized by their ethnic and gender identities were able to ameliorate their marginal status while also having a profound impact on the way the Anlo defined the boundaries that separated "we" from "they" and managed the marital affairs of their young.

Only by analyzing the interconnections between gender and ethnic relations is it possible to understand the extent to which social relations involving one set of defined identities is necessarily connected to other identities and social relations. For pre-colonial African history, such an analysis also helps avoid the all-too-common tendency to portray both "oppressor" and "oppressed" in one-dimensional terms where, for example,

28. Binetsch, "Beantwortung mehrerer", p. 46. 
men are simply misogynists and women simply marginal to the political and social affairs of the entire society. Avoiding such simplistic portrayals is especially important within the field of pre-colonial African history because African men and women have been steeped for far too long in the racist imagery that continues to influence the way others see Africa, Africans and African culture. By analyzing gender and ethnicity together within the same study as inextricably connected phenomena, one can more accurately represent the histories of African peoples in all their complexities. 